\title{
Detection of Goat Digestive Tract Protozoa Through Feces Examination in Kwanyar Sub-District, Bangkalan District
}

\author{
${ }^{1)}$ Meyreta Doti Alcaterana, ${ }^{2)}$ Poedji Hastutiek ${ }^{(D)}{ }^{2)}$ Nunuk Dyah Retno Lastuti, ${ }^{2)}$ Endang \\ Suprihati, ${ }^{2)}$ Agus Sunarso \\ ${ }^{1)}$ Student, Faculty of Veterinary Medicine, Universitas Airlangga, mayretadotialcaterana@gmail.com \\ ${ }^{2}$ Division of Veterinary Parasitology, Faculty of Veterinary Medicine, Universitas Airlangga \\ Received: 15-08-2021, Accepted: 25-08-2021, Published Online: 30-09-2021
}

Corresponding author: poedjihastutiek@gmail.com

\begin{abstract}
This study aims to determine the prevalence and species of protozoa that infect the digestive tract of goats in Kwanyar Sub-District, Bangkalan District. This study was conducted in June-July 2019 with 100 samples of stool examination in the laboratory of the Division of Parasitology, Faculty of Veterinary Medicine, Airlangga University. On examination found two types of protozoa, which were: Eimeria sp and Blastocystis sp. The results of this study showed the prevalence of $48 \%$ digestive tract protozoa. The results of statistical analysis using the Chi-Square test showed significant differences in age under one year and over one year in goats $(\mathrm{p}<0.05)$.
\end{abstract}

\section{Keywords: Eimeria sp, Blastocystis sp, Kwanyar, Goat, Bangkalan District, Protozoa}

\section{Introduction}

Bangkalan District is one of the Districts that has a large population of goats, according to data from the Animal Husbandry Service of East Java Province (2016) Bangkalan District has a goat population of 73,003 heads, one of the SubDistricts that has a large goat population is Kwanyar Sub-District with a goat population of 73,003 4,112 heads, this shows that many people raise goats. Raising goats usually has several obstacles faced, the main disease of goats is a parasitic disease of the digestive tract that inhibits livestock growth, weight loss, and causes economic losses for farmers. Single or mixed infection by coccidia greatly affects the production, even death of young livestock (Winarso, 2018). Based on research conducted by Hastutiek, et al., (2019) in 1o Sub-Districts in Bangkalan District, Madura cattle showed high results, namely $71.4 \%$ of the samples tested positive for gastrointestinal protozoa, which consisted of species Eimeria sp, Balantidium sp, Isospora sp, Blastocystis sp, Entamoeba sp, and Criptosporidium sp. Research on gastrointestinal protozoa conducted in Kwanyar Sub-District found 50 stool samples, $50 \%$ of which were positive and zoonotic, consisting of species Blastocystis hominis, Balantidium coli, and Entamoeba sp (Hastutiek et al., 2018). Cases in cattle can occur in goats and can be transmitted to humans including Blastocystis sp with clinical symptoms in the form of abdominal pain, bloating, and diarrhea (Badparva et al., 2015). Balantidium sp in acute infection can cause abscesses and ulcers in the mucosa and submucosa of the large intestine with a picture like amoebic dysentery (Yulfi, 2006)

\section{Materials and Methods}

Fecal samples that have been taken are placed in a stool pot. Due to the distance between the sampling sites, the sample was added with $2.5 \%$ potassium bichromate as a preservative and then labeled with the owner's name, age, gender, and sampling location (Suwanti et al, 2011). Then the sample was put into an ice box to be taken to the laboratory. The feces were made into a suspension with a ratio of $1: 10$ and then filtered. The filtrate obtained was put into a centrifuge tube and then centrifuged at $1500 \mathrm{rpm}$ for two to five minutes. Furthermore, the supernatant was discarded, then added with aquadest and centrifuged again. This was done repeatedly until the supernatant looks clear and a clear sugar solution was added up to $1 \mathrm{~cm}$ from the mouth of the tube, then stirred with a stirrer. Then it was centrifuged at $1500 \mathrm{rpm}$ for three to 5 minutes. Then a clear sugar solution was added using a pipette until the surface looked convex. Then the cover glass was placed on the surface of the tube for 5 minutes. The cover glass was removed and then placed on the object glass and examined under a microscope with a 
magnification of 100x-400x (Suwanti et al, 2011). The results of the examination were declared positive if protozoa were found from the fecal examination method. Protozoa identification was carried out by looking at the morphology and measurements of the protozoa using the Soulsby (1986) identification key.

A positive sample was calculated the prevalence rate with the formula:

\section{Prevalence $=$ Number of infected samples $\mathrm{x} 100 \%$ Number of samples observed}

The prevalence results indicated the level of a problem in the disease for administrative purposes and can be used as a strategic consideration in disease control (Thrusfield, 2005). The results of observations regarding the detection of digestive tract protozoa in goats were analyzed qualitatively by calculating the percentage of positive samples. Examination of the infective stage of the protozoa in feces was analyzed using the Chi-Square test. Statistical analysis using the SPSS (Statistical Product and Service Solution) for Windows rel 22.0 program.

\section{Results and Discussion}

Based on laboratory examinations using the floating method on 100 samples of goat feces taken in Kwanyar Sub-District, Bangkalan
District, precisely in Dlemer Village during June 2019 to July 2019, 48 samples were positive and 52 were negative. The results of the prevalence of digestive tract protozoan infections in goats in Kwanyar Sub-District, Bangkalan District can be seen in Table 1.

Protozoa found in this study were Blastocystis sp, and Eimeria sp. Protozoa identification is done by observing the morphology of the shape and size of the protozoa. Protozoa were measured and observed with a microscope connected to an optilab. Eimeria sp. was the main single infection, the lowest single infection was Blastocystis sp. In mixed infections, namely Eimeria sp. and Blastocystis sp. measurement of protozoa using Imageraster program. The types of protozoa found in goats can be seen in Table 1.

The Eimeria sp. oocyst found in this study was oval in shape, had a thin and smooth wall, had 4 sporocysts, Eimeria sp. had a size of $29.3 \mathrm{X}$ $19.8 \mathrm{~m}$. Eimeria sp. became the single highest source of infection with 34 positive samples from 100 samples, the second single source of infection was Blastocystis sp. as many as 6 positive samples from 100 samples and mixed infection sources by 8 samples from 100 samples. Images of Eimeria sp. can be seen in Figures 1 and 2.

Table 1. Prevalence of Gastrointestinal Protozoa Infection in Goats in Kwanyar Sub-District, Bangkalan District

\begin{tabular}{|c|c|c|c|c|c|c|}
\hline \multirow{2}{*}{ Sample } & \multicolumn{3}{|c|}{ Infection } & \multicolumn{3}{|c|}{ Type } \\
\hline & $\begin{array}{c}\text { Kind of } \\
\text { Infection }\end{array}$ & Number & Percentage & Protozoa & Number & Percentage \\
\hline \multirow[t]{3}{*}{ Positive } & Single & $40 / 48$ & 40 & Eimeria sp & $34 / 48$ & 34 \\
\hline & & & & $\begin{array}{l}\text { Blastocystis } \\
\text { sp. }\end{array}$ & $6 / 48$ & 6 \\
\hline & Double & $8 / 48$ & 8 & $\begin{array}{l}\text { Eimeria sp. } \\
\text { and } \\
\text { Blastocystis sp. }\end{array}$ & $8 / 48$ & 8 \\
\hline Negative & - & 52 & 52 & - & 52 & 52 \\
\hline Total & - & 100 & 100 & - & 100 & 100 \\
\hline
\end{tabular}




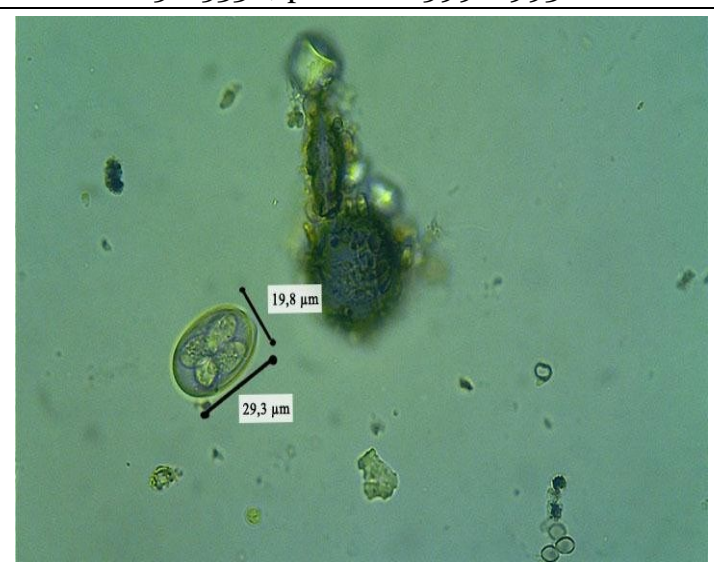

Figure 1. Sporulated Eimeria sp oocyst, four sporocysts were found through examination using floating method (40ox magnification).

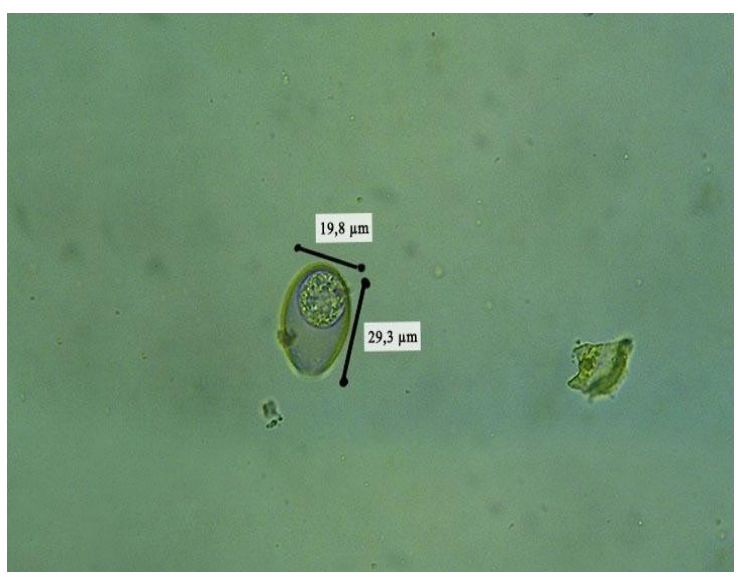

Figure 2. Unsporulated Eimeria sp. oocyst was examined by floating methods (40ox magnification)

Blastocystis sp. cyst found in this study measuring $21.3 \times 20.1 \mu \mathrm{m}$ thick-walled, consisting of many vacuoles, having 1-2 nuclei. Having positive single infection in 6 out of 100 samples and mixed infection with Eimeria sp. as many as 8 of 100 samples. Blastocystis sp. can be seen in Figure 3 .

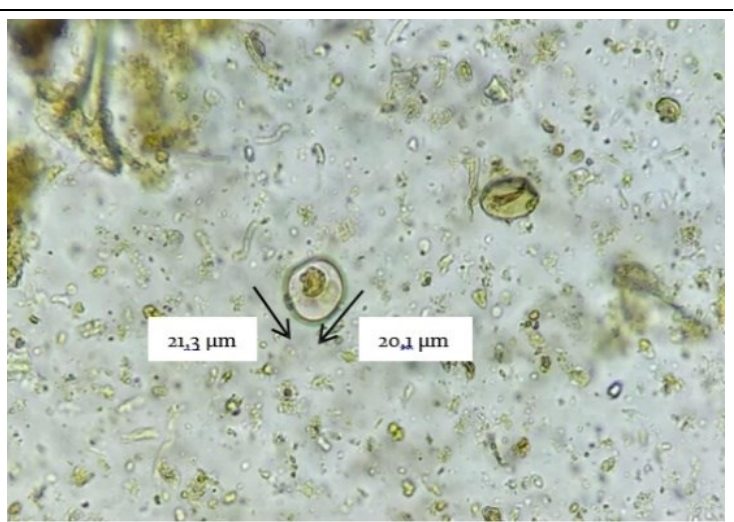

Figure 3. Blastocystis sp cyst was examined by the floating method (40ox magnification).

The results of microscopic examination showed that 19 goats (39.6\%) aged over one year were positively infected with digestive tract protozoa and 29 goats (60.4\%) aged under one year were positively infected with digestive tract protozoa. The results of the prevalence of digestive tract protozoa by age and type of protozoa can be seen in Table 2.

\section{Conclusions}

Examination of 100 fecal samples in goats in Kwanyar Sub-District, Bangkalan District, the types of protozoa found were Eimeria sp and Blastocystis sp. The prevalence of digestive tract protozoal infection in goats in Kwanyar SubDistrict, Bangkalan District was $48 \%$. The prevalence of gastrointestinal protozoa infection in goats is influenced by the age of the goats, which can be seen from the prevalence percentage of goats aged more than one year of $39.6 \%$ and goats aged less than one year of $60.4 \%$.

Table 2. Prevalence of Gastrointestinal Protozoa Infection in Goats in Kwanyar Sub-District, Bangkalan District based on Age and Type of Protozoa.

\begin{tabular}{lccc}
\hline \multicolumn{1}{c}{ Kind of Protozoa } & Infected Sample & \multicolumn{2}{c}{ Prevalence $(\%)$} \\
\cline { 3 - 4 } & & Age is less than 1 year & Age is more 1 year \\
\hline Eimeria sp & 34 & $17 / 48(35.4)$ & $17 / 48(35.4)$ \\
Blastocystis sp. & 6 & $4 / 48(8.3)$ & $2 / 48(4.2)$ \\
Eimeria sp. and & 8 & $8 / 48(16.7)$ & $0 / 48$ \\
Blastocystis sp. & & & $19 / 48(39.6)$
\end{tabular}




\section{References}

Dinas Peternakan Provinsi Jawa Timur. 2016. Data Statistik Populasi Ternak. //www.disnak.jatimprov.go.id/.

Hastutiek, P., Yuniarti. W.M, Mufasirin, Lastuti, N.D.R, Suprihati, E, and Suwanti, L.T. 2019. Prevalence and Diversity of Gastrointestinal Protozoa in Madura Cattle at Bangkalan.Veterinary World. 12(2):198204.

Winarso, A. 2018. Infeksi Parasit Gastrointestinal pada kambing di Kupang. Fakultas Kedokteran Hewan, Universitas Nusa Cendana, Nusa Tenggara Timur. Arshi Veteriner Letters. 2(2):25-26.

Hastutiek, P., Lastuti, N.D.R, dan Mufasirin. 2018. Deteksi Penyakit Parasit Intestinal Zoonosis Sebagai Penyakit Strategis pada Sapi Madura. Laporan Penelitian Unggulan Fakultas Kedokteran Hewan Universitas Airlangga.
Badparva, E. Fallahi, S., Mazar, Z.E. 2015. Blastocystis: Emerging Protozoan Parasite with High Prevalence in Iran. Novelty in Biomedicine. 4:214-221

Yulfi, H. 2006. Protozoa Intestinalis [Skripsi]. Universitas Sumatera Utara. Medan.

Suwanti, L.T., N.D.R. Lastuti, Mufasirin, dan E. Suprihati. 2011. Petunjuk dan Laporan Praktikum Ilmu Penyakit Protozoa. Fakultas Kedokteran Hewan. Universitas Airlangga. 9-11.

Soulsby, E. J. L. 1986. Helminths, Arthropds and Protozoa of Domesticated Animals. The English language book society and bailliere, Tindall. London. 577-749. 